\title{
The cost of implementing OHSMS regulation on high-rise building projects
}

\author{
Reini D. Wirahadikusumah ${ }^{1, *}$ and Felix Adhiwira ${ }^{2}$ \\ ${ }^{1}$ Construction Engineering and Management Research Group, Faculty of Civil and Environmental Engineering, Institut Teknologi \\ Bandung, Bandung, Indonesia \\ ${ }^{2}$ Magister Study Program of Civil Engineering, Faculty of Civil and Environmental Engineering, Institut Teknologi Bandung, \\ Bandung, Indonesia
}

\begin{abstract}
In 2014, the Ministry of Public Works and Housing have published regulation that require the full implementation of Occupational Safety and Health Management System or short as OHSMS (known as SMK3 in Indonesia) in all phases of construction projects. The so called PerMenPUPR 5/2014 imposed an allocation of cost specific for OHSMS in the owner's estimate, which was later updated as PerMenPUPR 2/2018 for minor adjustments in the regulation. This regulation was supported with guidelines for project managers on estimating the cost allocation for OHSMS. However, the initiative to address safety issues more comprehensively has been ineffective. The directive has not been seriously implemented by stakeholders on public projects. Thus, to help convince all stakeholders, more quantitative evidence on the costs for implementing OHSMS is pursued. This study is to determine the percentage of costs allocated by contractors for the procurement of OHSMS components. Data were collected from surveys to eight construction sites of high-rise building projects in Jakarta and Bandung. Based on interviews, questionnaires, and supporting documents from each case study, the cost of implementing the regulation was simulated and estimated. The cost allocation ranges from $2.01 \%$ to $3.70 \%$ of the contract value. The most significant components of the costs were related to $\mathrm{OSH}$ personnel $(44.10 \%)$, insurance and licensing $(35.2 \%)$, and OSH induction and promotion $(5.82 \%)$.
\end{abstract}

\section{Introduction}

Construction sector has a very important role in Indonesia's economic growth. It is the third biggest driver in 2016 , contributing to $30.5 \%$ of Indonesian GDP. In the first quarter of 2018, the contribution of the construction sector to GDP alone was recorded at $10.5 \%$ or worth Rp.367,8 trillion (approximately US $\$ 25,14$ billion) In terms of employment, the construction industry absorbs 8.14 million work forces (as of August 2017) [1].

However, the construction sector also has a much known reputation as one of the highest contributors to workplace accidents, not only in Indonesia, but also throughout the world. In 2014, based on the Indonesian social security agency data, the number of work accidents in this sector reached $32 \%$ of the total workplace accidents. Occupational accident data recorded by BPJS Ketenagakerjaan from 2014-2017 are 103,$235 ; 105,383 ; 110,272 ; 101,272$; and 123,041 cases per year, respectively. While real data on construction related accidents are not readily available, the figures are estimated to be about one-third of those. Also, it is commonly understood that accident data are in most cases underreported.

Numerous studies have indicated that workplace accident can be caused by many factors. Vasconcelos and Junior [2] recently explained that the major causes of work accidents are mostly caused by lack of planning and organization, unsafe workplace condition, and human factors, which relates to social problems, lack of training, and psychological cause. Also, stress coupled with thinking error is a significant factor according to Day et al. [3].

To improve the conditions, one aspect is that adequate budget must be allocated for preventive measures on construction sites. Owners are in many cases reluctant to put "more money" to address this issue, on the premise that it is the sole responsibility of the contractors and the contractors should completely accommodate the cost in their cost proposal. Project owners need to understand the magnitude of this cost and allocate sufficient budget and furthermore ensure that contractors will use it effectively.

Thus, the first step is to obtain the general estimate regarding the percentage of costs allocated by

\footnotetext{
* Corresponding author: reiniwhk@gmail.com
} 
contractors for the implementation of Occupational Health and Safety Management System (OHSMS), which is mandatory in all high-risk construction sites. Earlier work based on data collected in 2014, the minimum required cost components for effective implementation of OHSMS has been identified in Wirahadikusumah and Marbun [4]. Follow up study on the magnitude of cost to implement such system, when complying with PerMenPUPR 2/2018, is explained next.

\section{The practice of OHSMS in construction projects}

Since 2012, it has been mandatory for companies with 100 plus employees and/or for companies with high-risk activities, which include construction business, to implement Sistem Manajemen Keselamatan dan Kesehatan Kerja (SMK3) or OHSMS [9]. PP 50/2012 on SMK3 or OHSMS applies on all firms with such characteristics, both private and public companies.

Following up on PP 50/2012, more specific guidelines for the purpose of the construction industry were needed. Thus, the application of OHSMS for the construction industry has been regulated in the Ministry of Public Works, i.e., PerMen PUPRR 05/PRT/M/2014 and then updated as PerMenPUPR $02 / \mathrm{PRT} / \mathrm{M} / 2018$. This regulation oversees the implementation of construction work to meet the safety, security, and occupational health requirements of all parties involved in construction activities to create a culture of orderly execution of construction work.

The main objectives of the implementation of this regulation are:

i) to improve the effectiveness of planned, measured, structured, and integrated protection of occupational health and health;

ii) to prevent and reduce work accidents and occupational diseases; and

iii) to create a safe, comfortable and efficient workplace to encourage productivity. While PerMenPUPR 02 /PRT/M/2018 is mandatory only within the Ministry of Public Works and Housing. These guidelines can be used as a reference in other sector of the construction industry.

To effectively reduce the number of accidents and occupational diseases, a comprehensive integrated system from top level management to field operation workers is needed. Management support has the greatest impact on the OHS programs that have been arranged. All safety programs that have been planned will not work properly without the support of management. This is due to management functions relating to the allocation of resources (especially money and workers), actively holding safety meetings, investigating and establishing corrective actions on each accident, and convincing all employees to be involved in carrying out its role in the safety program (Aksorn and Hadikusumo). [5]

The importance of the management role is also stated by Hallowell and Gambatese [6]. Their study suggested that there are four tiers of effectiveness of safety program elements to reduce occupational safety and health hazards on construction sites. The first are support and commitment from the upper management, second-tier elements are employee involvement in safety management, jobsite analysis, safety training, regular safety meeting, and inspection. The third tier consists of safety and health committees, safety orientation, and safety plan. And the fourth tier involves the importance of record keeping, accident analysis, and emergency plan.

Implementation of OHSMS has proven to be effective in terms of preventing workplace accidents and fatality rate. A study conducted in South Korea by Yoon et al. [7 showed that accident rates in KOSHA 18001 certified companies were much lower, by $67 \%$, than their non-certified counterparts. KOSHA 18001 is a certification system for companies implementing OHSMS in South Korea. Fatality rates were also measured between these two groups of companies, which resulted that in KOSHA-certified companies, the number of fatalities could be reduced by $10,3 \%$. Thus, Yoon et al. concluded that the differences in accident rates were related to the implementation of OHSMS.

OHSMS has been recognized also as an approach to improve the transparency, productivity, and competitiveness of the company [7]. Increased productivity can occur if a situation and a safe working environment are created. A supportive work environment can reduce the risk of accidents or health so that workers can focus on their duties.

While the implementation of such system has been mandatory, OHSMS is not effectively practiced by Indonesia contractors. A study conducted by Machdufiyanto et al. [8] concluded that the implementation rate of OHSMS in construction projects was low. More than $70 \%$ of surveyed construction projects did not implement such system. Similarly, only one-third of big firms complied with the regulation to carry out OHSMS in their projects.

\section{The costs of OHSMS}

While it is the responsibility of the contractors to work safely and allocate enough funding in their cost proposal, the owners need to understand the magnitude of the funding and its consequences. The owners are responsible to ensure that contractors will use it effectively.

The cost for implementing OHSMS in the context of complying to the regulation, i.e., PerMenPUPR 2/2018, is further explained in the supplemented SE Menteri PUPR 66/2015 [12]. In this operational directive, there is a detailed list of all components of OHSMS for construction sites, as shown in Table 1. 
Table 1. OHSMS cost components as regulated in SE Menteri PUPR 66/2015

\begin{tabular}{|c|c|c|c|}
\hline & $\begin{array}{c}\text { Cost } \\
\text { components }\end{array}$ & & Descriptions \\
\hline 1 & $\begin{array}{l}\text { OSH } \\
\text { contract } \\
\text { plan } \\
\text { preparation }\end{array}$ & ii. & $\begin{array}{l}\text { preparation of work } \\
\text { manual, instruction, safety } \\
\text { procedure, work permit } \\
\text { workers and visitors } \\
\text { identification }\end{array}$ \\
\hline 2 & $\begin{array}{l}\text { OSH } \\
\text { induction } \\
\text { and } \\
\text { promotion }\end{array}$ & $\begin{array}{l}\text { i. } \\
\text { ii. } \\
\text { iii. } \\
\text { iv. }\end{array}$ & $\begin{array}{l}\text { safety briefing/ safety talk } \\
\text { / toolbox meeting } \\
\text { safety training and } \\
\text { simulation } \\
\text { banner, poster, } \\
\text { promotional media } \\
\text { informational and } \\
\text { statistical board }\end{array}$ \\
\hline 3 & $\begin{array}{l}\text { Safety } \\
\text { equipment }\end{array}$ & $\begin{array}{l}\text { i. } \\
\text { ii. } \\
\text { iii. } \\
\text { iv. }\end{array}$ & $\begin{array}{l}\text { safety net } \\
\text { safety line } \\
\text { fall arrester } \\
\text { guard rail and perimeter }\end{array}$ \\
\hline 4 & $\begin{array}{l}\text { Personnel } \\
\text { protective } \\
\text { equipment }\end{array}$ & $\begin{array}{l}\text { ii. } \\
\text { iii. } \\
\text { iv. }\end{array}$ & $\begin{array}{l}\text { helmet, safety shoes, safety } \\
\text { glasses, gloves, etc. } \\
\text { full body harness } \\
\text { breathing apparatus } \\
\text { life vest }\end{array}$ \\
\hline 5 & $\begin{array}{l}\text { Insurance } \\
\text { and } \\
\text { licensing }\end{array}$ & $\begin{array}{l}\text { i. } \\
\text { ii. } \\
\text { iii. }\end{array}$ & $\begin{array}{l}\text { insurance premium } \\
\text { equipment permit } \\
\text { operator's license }\end{array}$ \\
\hline 6 & $\begin{array}{l}\text { OSH } \\
\text { personnel }\end{array}$ & $\begin{array}{l}\text { i. } \\
\text { ii. } \\
\text { iii. } \\
\text { iv. }\end{array}$ & $\begin{array}{l}\text { SHE manager } \\
\text { SHE supervisor } \\
\text { emergency response } \\
\text { officer } \\
\text { medical officer }\end{array}$ \\
\hline 7 & $\begin{array}{l}\text { Health } \\
\text { facilities }\end{array}$ & $\begin{array}{l}\text { i. } \\
\text { ii. }\end{array}$ & $\begin{array}{l}\text { first aid equipment } \\
\text { first aid room }\end{array}$ \\
\hline 8 & Safety signs & $\begin{array}{l}\text { ii. } \\
\text { iii. }\end{array}$ & $\begin{array}{l}\text { instruction, prohibition, } \\
\text { warning, information signs } \\
\text { temporary barricade } \\
\text { traffic control signs }\end{array}$ \\
\hline 9 & $\begin{array}{l}\text { Others } \\
\text { related to } \\
\text { OHS risk } \\
\text { control }\end{array}$ & $\begin{array}{l}\text { i. } \\
\text { ii. } \\
\text { iii. } \\
\text { iv. }\end{array}$ & $\begin{array}{l}\text { firefighting equipment } \\
\text { emergency equipment } \\
\text { internal audit and } \\
\text { inspection program } \\
\text { incident report and } \\
\text { investigation }\end{array}$ \\
\hline
\end{tabular}

\section{Research Method}

The objective of this study is to obtain the general estimate regarding the percentage of costs allocated by contractors for the implementation of OHSMS and the supposed allocated funding as required PerMenPUPR
$2 / 2018$. Such cost is estimated following the cost components suggested in Table 1 .

Obtaining primary data in the construction sector is very difficult. However, any study pertaining to this industry can only be conducted using data and information via surveys and interviews. Construction projects data are not readily available through any institutions.

During the first few months of 2018, data were collected from eight cases which are all high-rise building projects in Jakarta areas. Each respondent (project manager or safety manager) was asked on how much he/she allocates funding for OHSMS in the project. While real figures were not given, they provided data on funding allocated in percentage to the total value of the contract. Other information regarding each project's OSH program was also gathered.

The allocated funding for OHSMS in the project, based on respondent's asnwer, was then labeled as "the actual budget." This actual budget was analyzed in order to identify whether the total value was sufficient and complying to the regulation.

The total value of OHSMS cost in each project, as suggested in the regulation (i.e., PerMenPUPR 2/2018, and SE Menteri PUPR 66/2015[12]), was calculated, and then named as "the simulated budget." The simulated budget was calculated based on the set of unit prices for each OSH cost components/items that were collected from the respondent's documents (i.e., bidding documents/proposals). In some occasions, those data were complemented with related information from interviews.

The "actual cost" and the "simulated cost" of each project were compared. Results and discussions were followed. This study involved only eight cases and serves as a preliminary study. While sound conclusion cannot be drawn, the method can be replicated for further study as more accessible data are available in the future.

\section{Results}

The eight cases are listed in Table 2. The corresponding data on the actual and simulated budget of OHSMS are shown in Table 3. The simulated budget of OHSMS were calculated based on site observations. The guidelines [12] to calculate the simulated budget were closely followed.

Table 2. Respondents in the case study

\begin{tabular}{|c|c|c|c|c|c|}
\hline $\begin{array}{c}\text { Project } \\
\text { name }\end{array}$ & $\begin{array}{l}\text { Bldg } \\
\text { type }\end{array}$ & \# of Floors & $\begin{array}{c}\text { Ave } \\
\text { rage } \\
\text { of } \\
\text { Wor } \\
\text { kers }\end{array}$ & $\begin{array}{c}\text { Pro } \\
\text { ject } \\
\text { Dura } \\
\text { tion } \\
\text { (mon } \\
\text { ths) } \\
\end{array}$ & $\begin{array}{c}\text { Con } \\
\text { tract } \\
\text { value } \\
\text { (in } \\
\text { IDR) }\end{array}$ \\
\hline Project 1 & $\begin{array}{l}\text { Mixed- } \\
\text { use }\end{array}$ & $\begin{array}{l}2 \text { towers } \\
\text { @ } 30 \text { floors }\end{array}$ & 500 & 36 & $\begin{array}{c}500 \\
\text { billion }\end{array}$ \\
\hline Project 2 & $\begin{array}{l}\text { Mixed- } \\
\text { use }\end{array}$ & $\begin{array}{l}2 \text { towers } \\
\text { @ } 40 \text { floors }\end{array}$ & 500 & 24 & $\begin{array}{l}400 \\
\text { billion }\end{array}$ \\
\hline
\end{tabular}




\begin{tabular}{|c|c|c|c|c|c|}
\hline $\begin{array}{r}\text { Project } \\
\text { name }\end{array}$ & $\begin{array}{l}\text { Bldg } \\
\text { type }\end{array}$ & \# of Floors & $\begin{array}{c}\text { Ave } \\
\text { rage } \\
\text { of } \\
\text { Wor } \\
\text { kers }\end{array}$ & $\begin{array}{c}\text { Pro } \\
\text { ject } \\
\text { Dura } \\
\text { tion } \\
\text { (mon } \\
\text { ths) } \\
\end{array}$ & $\begin{array}{c}\text { Con } \\
\text { tract } \\
\text { value } \\
\text { (in } \\
\text { IDR) }\end{array}$ \\
\hline Project 3 & $\begin{array}{c}\text { Apart } \\
\text { ment }\end{array}$ & $\begin{array}{c}2 \text { towers } \\
\text { @38 floors }\end{array}$ & 500 & 24 & $\begin{array}{c}300 \\
\text { billion }\end{array}$ \\
\hline Project 4 & Office & $\begin{array}{l}2 \text { towers } \\
\text { @36 floors }\end{array}$ & 225 & 24 & $\begin{array}{c}225 \\
\text { billion }\end{array}$ \\
\hline Project 5 & $\begin{array}{l}\text { Mixed- } \\
\text { use }\end{array}$ & $\begin{array}{l}2 \text { towers } \\
@ 27 \text { floors }\end{array}$ & 241 & 30 & $\begin{array}{c}210 \\
\text { billion }\end{array}$ \\
\hline Project 6 & Office & $\begin{array}{l}1 \text { tower } \\
\text { @2 } 20 \text { floors }\end{array}$ & 150 & 24 & $\begin{array}{c}150 \\
\text { billion }\end{array}$ \\
\hline Project 7 & Office & $\begin{array}{l}2 \text { towers } \\
@ 37 \text { floors }\end{array}$ & 350 & 24 & $\begin{array}{c}140 \\
\text { billion }\end{array}$ \\
\hline Project 8 & Office & $\begin{array}{l}1 \text { tower } \\
\text { @ } 38 \text { floors }\end{array}$ & 125 & 24 & $\begin{array}{c}93.5 \\
\text { billion }\end{array}$ \\
\hline
\end{tabular}

Table 3. OHSMS actual budget v. simulated budget

\begin{tabular}{ccc}
\hline Project name & $\begin{array}{c}\text { OHSMS } \\
\text { actual } \\
\text { budget }\end{array}$ & $\begin{array}{c}\text { OHSMS } \\
\text { simulated } \\
\text { budget }\end{array}$ \\
\hline Project 1 & $2.0 \%$ & $2.18 \%$ \\
Project 2 & $2.0 \%$ & $3.45 \%$ \\
Project 3 & $2.0 \%$ & $2.38 \%$ \\
Project 4 & $1.5 \%$ & $2.01 \%$ \\
Project 5 & $1.5 \%$ & $3.33 \%$ \\
Project 6 & $1.25 \%$ & $2.46 \%$ \\
Project 7 & $1.5 \%$ & $3.70 \%$ \\
Project 8 & $1.0 \%$ & $2.04 \%$ \\
\hline Average & $1.59 \%$ & 2.66 \\
\hline
\end{tabular}

From Table 3, it can be seen that the cost of OHSMS budgeted by all respondents were less than the simulated budget according to the regulation.

The "ideal" budget or costs for implementing OHSMS on those eight sites range from $2.01 \%$ to $3.70 \%$ of the total value of each project. This may indicate that some of the OSH components mandated in the regulations were not fully implemented in the projects, or also because the components listed in the regulations were not considered as necessary as OSH components by the contractors.

The data collected were also analyzed for identifying the most dominant cost components, as shown in Table 4. The three most dominant cost components are $\mathrm{OSH}$ personnel $(44.10 \%)$, Insurance and licensing $(35.42 \%)$, and OSH induction and promotion (5.82\%).

Table 4. OHSMS' most significant cost components

\begin{tabular}{|c|c|c|}
\hline Rank & Cost component & $\begin{array}{l}\text { Percentage } \\
\text { to } \\
\text { the contract } \\
\text { value }\end{array}$ \\
\hline 1 & OSH personnel & $44.10 \%$ \\
\hline 2 & $\begin{array}{l}\text { Insurance and } \\
\text { licensing }\end{array}$ & $35.42 \%$ \\
\hline 3 & $\begin{array}{l}\text { OSH induction and } \\
\text { promotion }\end{array}$ & $5.82 \%$ \\
\hline
\end{tabular}

\begin{tabular}{|c|c|c|}
\hline Rank & Cost component & $\begin{array}{c}\text { Percentage } \\
\text { to } \\
\text { the contract } \\
\text { value } \\
\end{array}$ \\
\hline 4 & $\begin{array}{l}\text { Personnel protective } \\
\text { equipment }\end{array}$ & $5.23 \%$ \\
\hline 5 & Safety equipment & $3.87 \%$ \\
\hline 6 & $\begin{array}{l}\text { Others Related to OHS } \\
\text { Risk Control }\end{array}$ & $2.90 \%$ \\
\hline 7 & Health facility & $1.46 \%$ \\
\hline 8 & $\begin{array}{l}\text { OSH contract plan } \\
\text { preparation }\end{array}$ & $0.61 \%$ \\
\hline 9 & Signs & $0.59 \%$ \\
\hline
\end{tabular}

Cost for OSH personnel is proportional to the number of workers. In addition, high-rise building construction projects require a number of safety supervisors. Insurance and licensing are necessary and the cost is quite significant for the contractor, as a mitigating effort of accidents. OSH induction and promotion costs are used for OSH regular meetings, trainings and emergency response simulations. The use of uncommon work methods or materials require more extensive training for workers to be able to do the work properly and safely. Workers must also be reminded to prioritize safety during the whole construction period at meetings held regularly.

\section{Discusion - Factors Affecting OHSMS Budget}

While the actual allocation by respondents were lower than "ideal", the simulated budgets (calculated based on the regulation) on eight case studies can be used to provide a general overview of the OSHMS budget for high-rise building projects. Tables $5,6,7$, and 8 show the budget needed per square meter, per floor, per worker, and per month.

Table 5. OHSMS simulated budget per square meter

\begin{tabular}{|c|c|c|c|c|}
\hline $\begin{array}{c}\text { Pro } \\
\text { ject } \\
\#\end{array}$ & $\begin{array}{c}\text { Contract } \\
\text { Value } \\
\text { (in IDR) }\end{array}$ & $\begin{array}{c}\text { OHSMS } \\
\text { Budget } \\
\text { (in IDR) }\end{array}$ & $\begin{array}{c}\text { Total } \\
\text { Area } \\
\text { (m²) }^{2}\end{array}$ & $\begin{array}{c}\text { OHSMS } \\
\text { budget } \\
\text { per } \\
\text { square } \\
\text { meter } \\
\text { (in IDR) }\end{array}$ \\
\hline 1 & $\begin{array}{c}500 \\
\text { billion }\end{array}$ & $\begin{array}{c}10.920 \\
\text { billion }\end{array}$ & 182,248 & 59,922 \\
\hline 2 & $\begin{array}{c}400 \\
\text { billion }\end{array}$ & $\begin{array}{c}13.783 \\
\text { billion }\end{array}$ & 110,000 & 125,303 \\
\hline 3 & $\begin{array}{c}300 \\
\text { billion }\end{array}$ & $\begin{array}{c}7.151 \\
\text { billion }\end{array}$ & 105,588 & 67,728 \\
\hline 4 & $\begin{array}{c}225 \\
\text { billion }\end{array}$ & $\begin{array}{c}4.513 \\
\text { billion }\end{array}$ & 85,401 & 52,852 \\
\hline 5 & $\begin{array}{c}210 \\
\text { billion }\end{array}$ & $\begin{array}{c}6.997 \\
\text { billion }\end{array}$ & 82,916 & 84,387 \\
\hline 6 & $\begin{array}{c}150 \\
\text { billion }\end{array}$ & $\begin{array}{c}3.697 \\
\text { billion }\end{array}$ & 55,000 & 67,227 \\
\hline 7 & $\begin{array}{c}140 \\
\text { billion }\end{array}$ & $\begin{array}{c}5.183 \\
\text { billion }\end{array}$ & 50,364 & 102,913 \\
\hline
\end{tabular}




\begin{tabular}{|c|c|c|c|c|}
\hline $\begin{array}{c}\text { Pro } \\
\text { ject } \\
\#\end{array}$ & $\begin{array}{c}\text { Contract } \\
\text { Value } \\
\text { (in IDR) }\end{array}$ & $\begin{array}{c}\text { OHSMS } \\
\text { Budget } \\
\text { (in IDR) }\end{array}$ & $\begin{array}{c}\text { Total } \\
\text { Area } \\
\mathbf{( m}^{2} \text { ) }\end{array}$ & $\begin{array}{c}\text { OHSMS } \\
\text { budget } \\
\text { per } \\
\text { square } \\
\text { meter } \\
\text { (in IDR) }\end{array}$ \\
\hline 8 & $\begin{array}{c}93.5 \\
\text { billion }\end{array}$ & $\begin{array}{c}1.911 \\
\text { billion }\end{array}$ & 37,000 & 51,654 \\
\hline \multicolumn{4}{|c}{ Average } & 76,498 \\
\hline
\end{tabular}

Table 6. OHSMS simulated budget per number of workers

\begin{tabular}{|c|c|c|c|}
\hline $\begin{array}{c}\text { Pro } \\
\text { ject } \\
\#\end{array}$ & $\begin{array}{c}\text { OHSMS } \\
\text { Budget } \\
\text { (in IDR) }\end{array}$ & $\begin{array}{c}\text { Average } \\
\text { Number } \\
\text { of } \\
\text { Workers }\end{array}$ & $\begin{array}{c}\text { OHSMS } \\
\text { budget } \\
\text { per worker } \\
\text { (in IDR) }\end{array}$ \\
\hline 1 & $\begin{array}{l}10.920 \\
\text { billion }\end{array}$ & 500 & $21,841,396$ \\
\hline 2 & $\begin{array}{l}13.783 \\
\text { billion }\end{array}$ & 500 & $27,566,700$ \\
\hline 3 & $\begin{array}{c}7.151 \\
\text { billion }\end{array}$ & 500 & $14,302,552$ \\
\hline 7 & $\begin{array}{c}5.183 \\
\text { billion }\end{array}$ & 350 & $14,808,929$ \\
\hline 5 & $\begin{array}{c}6.997 \\
\text { billion }\end{array}$ & 241 & $29,033,207$ \\
\hline 4 & $\begin{array}{c}4.513 \\
\text { billion }\end{array}$ & 225 & $20,060,516$ \\
\hline 6 & $\begin{array}{c}3.697 \\
\text { billion }\end{array}$ & 150 & $24,649,983$ \\
\hline 8 & $\begin{array}{c}1.911 \\
\text { billion }\end{array}$ & 125 & $15,289,657$ \\
\hline \multicolumn{3}{|r|}{ Average } & $20,944,117$ \\
\hline
\end{tabular}

Table 7. OHSMS simulated budget per number floors

\begin{tabular}{|c|c|c|c|}
\hline $\begin{array}{c}\text { Pro } \\
\text { ject } \\
\#\end{array}$ & $\begin{array}{r}\text { OHSMS } \\
\text { Budget } \\
\text { (in IDR) }\end{array}$ & $\begin{array}{c}\text { Total } \\
\text { Number } \\
\text { of Floors }\end{array}$ & $\begin{array}{c}\text { OHSMS } \\
\text { Budget } \\
\text { per floor } \\
\text { (in IDR) }\end{array}$ \\
\hline 2 & $\begin{array}{l}13.783 \\
\text { billion }\end{array}$ & $2 @ 40=80$ & $172,291,875$ \\
\hline 3 & $\begin{array}{c}7.151 \\
\text { billion }\end{array}$ & $2 @ 38=76$ & $94,095,734$ \\
\hline 8 & $\begin{array}{l}1.911 \\
\text { billion }\end{array}$ & $1 @ 38=38$ & $50,294,924$ \\
\hline 7 & $\begin{array}{c}5.183 \\
\text { billion }\end{array}$ & $2 @ 37=74$ & $70,042,230$ \\
\hline 4 & $\begin{array}{l}4.513 \\
\text { billion }\end{array}$ & $2 @ 36=72$ & $62,689,111$ \\
\hline 1 & $\begin{array}{l}10.920 \\
\text { billion }\end{array}$ & $2 @ 30=60$ & $182,011,633$ \\
\hline 5 & $\begin{array}{l}6.997 \\
\text { billion }\end{array}$ & $2 @ 27=54$ & $129,574,130$ \\
\hline 6 & $\begin{array}{c}3.697 \\
\text { billion }\end{array}$ & $1 @ 20=20$ & $184,874,875$ \\
\hline \multicolumn{3}{|r|}{ Average } & $118,234,314$ \\
\hline
\end{tabular}

Table 8. OHSMS simulated budget per square meter per months during project duration

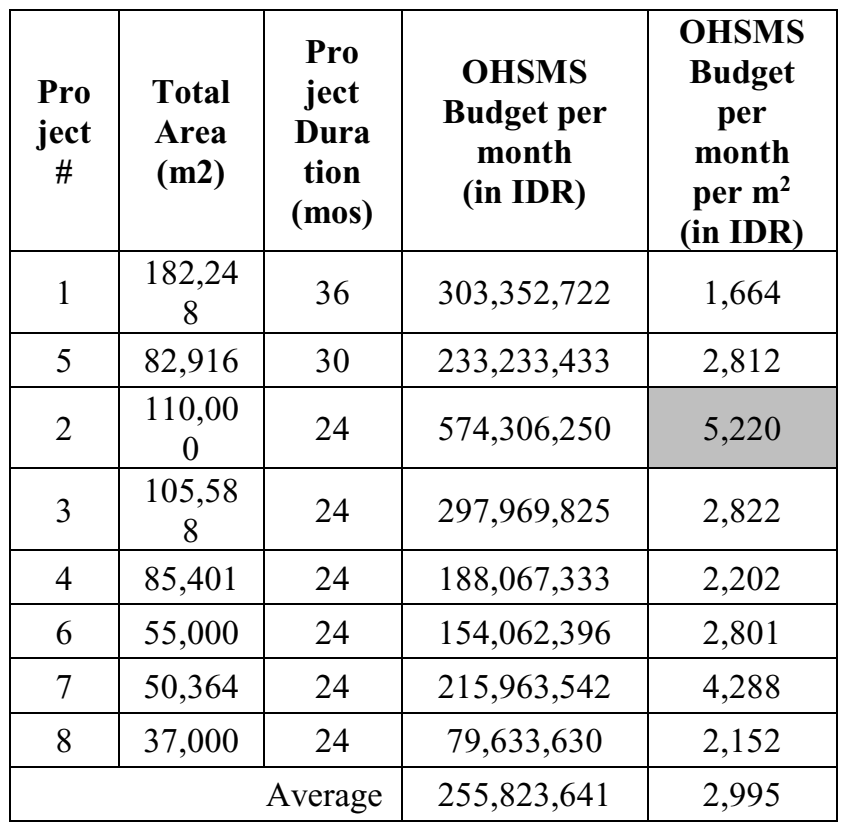

Highlights from Tables 5, 6, 7, and 8 are as follows:

i) The average cost of OHSMS which should be budgeted by the contractors per square meter was IDR 76,498. However, Project 2 spent much more than average which amounted to IDR 125,303 per square meter.

ii) Closer look at Table 7 suggest that the costs for "mid-rise" buildings (Project \#1, 5, and 6) were much higher than those for high-rise buildings (Projects \#2, 3, 8, 7, 4). However, again Project 2 allocated more money of this system.

iii) Based on the interviews, Project \#2 was actually more concerned about the site safety issues because they had a few accidents during the earlier stage of the project.

iv) Although other trends were not so obvious, the numbers shown on Tables 5, 6, 7, 8 can be used for future references during the planning stages of project development by the contractor and the owner as well.

Another note is that the "simulated budget," which was calculated following to the regulation, might have different interpretation. The "actual budget" cannot be simply compared to the "simulated budget" because the actual budget was not necessarily allocated following to the regulation. The regulation that was used as a reference in calculating the "simulated" or "ideal" OSHMS cost allocation is mandatory only within the Ministry of Public Works and Housing. All eight cases are not projects related to the Ministry. However, the comparisons as shown in this study provide general overview of the financial aspect of OSHMS. 


\section{Conclusion}

This study involved only eight cases, however it can provide a general indication regarding the magnitude of OSHMS cost allocation in construction sites which were much lower than needed to provide an effective management system. The more ideal budget was estimated to be about $2.01 \%-3.70 \%$, as mandated by PerMen PUPR 2/2018. The most significant contributors to the budget are the salary for SHE personnel/supervisors, the premium for insurance and licensing, and costs associated for promotion/training of OSH programs. Further study will explore the relationship between the costs and the general characteristics of construction projects, based on risk analysis during construction period.

\section{References}

1. BPS (2017): Pertumbuhan Ekonomi Indonesia Triwulan I-2017, Berita Resmi Statistik No. 45/05/Th.XX, 05 Mei 2017

2. B. Vasconcelos and B. B. Junior, (2015): The Causes of Work Place Accidents and Their Relation to Construction Equipment Design. Procedia Manufacturing 3 (2015) 4392-4399.

3. A. J. Day, K. Brasher, and R. S. Bridger, Accident proneness revisited: the role of psychological stress and cognitive failure. Accid. Anal. Prev. 49, 532535 (2012)

4. R. Wirahadikusumah and I. K. Marbun, Cost Components for Effective Safety and Health Management Program on Construction Projects. CIB W099 (2015).

5. T. Aksorn and B. H. W. Hadikusumo: Critical Success Factors Influencing Safety Program Performance in Thai Construction Projects, Safety Science 46 (2008), 709-727.

6. M. R. Hallowell, and J. A. Gambatese, Construction Safety Risk Mitigation. Journal of Construction Engineering and Management., (2009) 135(12): 1316-1323.

7. S. J. Yoon, H. K. Lin, G. Chen, S. Yi, J. Choi, and Z. Rui., Effect of Occupational Health and Safety Management System on Work-Related Accident Rate and Differences of Occupational Health and Safety Management System Awareness between Managers in South Korea's Construction Industry. Safe Health Work. (2013); 4:201-209

8. R. A. Machfudiyanto, Y. Latief, R. Arifuddin and Y. Yogiswara, Identification of Safety Culture Dimensions Based on Implementation of OSH Management System in Construction Company. Procedia (2017)

9. Peraturan Pemerintah no. 50/2012: tentang Penerapan Sistem Manajemen Keselamatan Dan Kesehatan Kerja

10. Permen. PUPR no 5 tahun 2014: tentang Pedoman SMK3 Konstruksi Bidang PU

11. Permen PUPR no 2 tahun 2018 tentang Perubahan Atas Peraturan Menteri Pekerjaan Umum Nomor
05/PRT/M/2014 Tentang Pedoman Sistem Manajemen Keselamatan dan Kesehatan Kerja (SMK3) Konstruksi Bidang Pekerjaan Umum.

12. Surat Edaran Menteri PUPR no. 66/SE/M/2015: tentang Biaya Penyelenggaraan SMK3 Konstruksi Bidang PU 